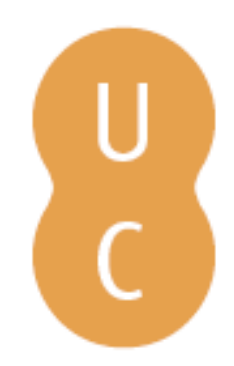

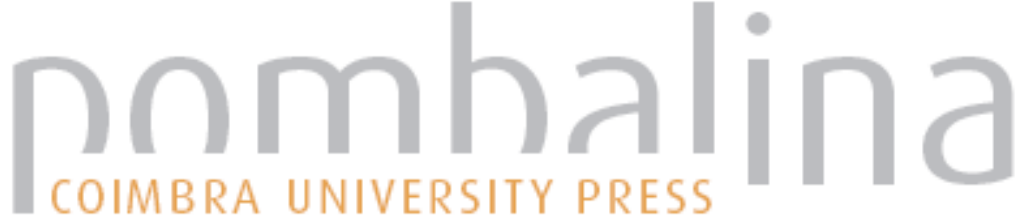

Fake news: a novidade das velhas falsificações

Autor(es): $\quad$ Silva, Juremir Machado da

Publicado por: Imprensa da Universidade de Coimbra

URL

persistente: URI:http://hdl.handle.net/10316.2/47346

DOI: $\quad$ DOl:https://doi.org/10.14195/978-989-26-1778-7_3

Accessed : $\quad$ 26-Apr-2023 05:05:32

A navegação consulta e descarregamento dos títulos inseridos nas Bibliotecas Digitais UC Digitalis, UC Pombalina e UC Impactum, pressupõem a aceitação plena e sem reservas dos Termos e Condições de Uso destas Bibliotecas Digitais, disponíveis em https://digitalis.uc.pt/pt-pt/termos.

Conforme exposto nos referidos Termos e Condições de Uso, o descarregamento de títulos de acesso restrito requer uma licença válida de autorização devendo o utilizador aceder ao(s) documento(s) a partir de um endereço de IP da instituição detentora da supramencionada licença.

Ao utilizador é apenas permitido o descarregamento para uso pessoal, pelo que o emprego do(s) título(s) descarregado(s) para outro fim, designadamente comercial, carece de autorização do respetivo autor ou editor da obra.

Na medida em que todas as obras da UC Digitalis se encontram protegidas pelo Código do Direito de Autor e Direitos Conexos e demais legislação aplicável, toda a cópia, parcial ou total, deste documento, nos casos em que é legalmente admitida, deverá conter ou fazer-se acompanhar por este aviso.

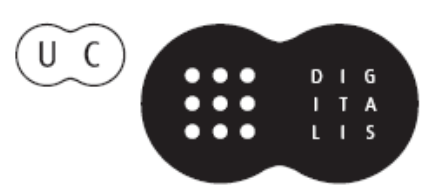




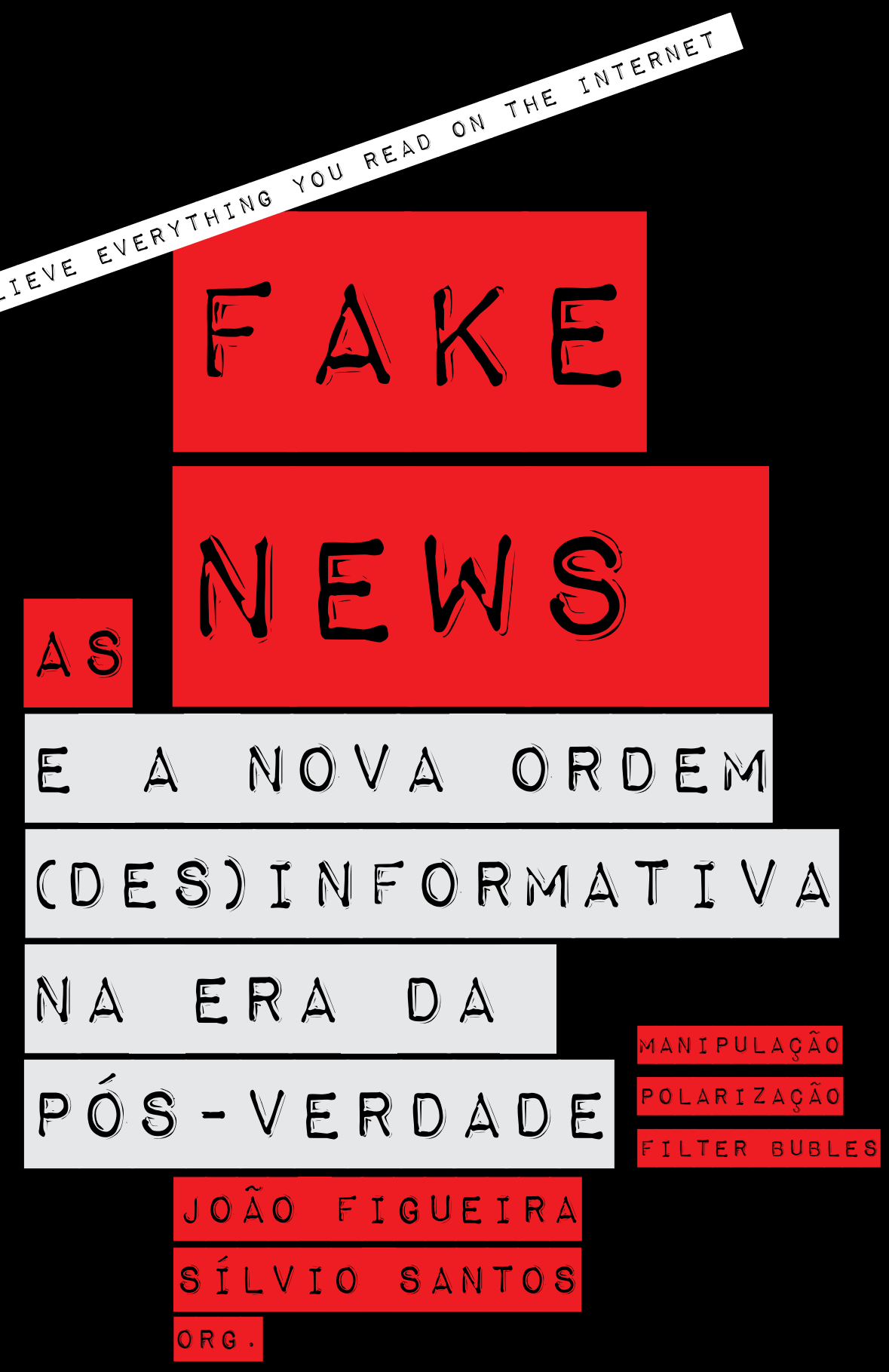

IMPRENSA DA UNIVERSIDADE DE COIMBRA

COIMBRA UNIVERSITY PRESS 
JUREMIR MACHADO DA SILVA

Pontifícia Universidade Católica do Rio Grande do Sul

https://orcid.org/0000-0001-8105-5596

FAKE NEWS, A NOVIDADE DAS VELHAS FALSIFICAÇÕES

FAKE NEWS, THE NOVELTY OF THE OLD FAKES

RESUMO: Este artigo examina o fenômeno chamado de fake news. À luz das ideias de dois intelectuais europeus, Jean Baudrillard e Umberto Eco, analisa a falsificação de notícias nas redes sociais como a aceleração de um antigo procedimento de disseminação de narrativas inverídicas.

Palavras-chave: Comunicação; Cultura; Mídia; Jornalismo; Internet

ABSTRACT: This article examines the phenomenon called fake news. In the light of the ideas of two European intellectuals, Jean Baudrillard and Umberto Eco, it analyzes the falsification of news on social networks as the acceleration of an old procedure of disseminating untrue narratives.

Keywords: Communication; Culture; Media; Journalism; Internet

\section{Velhas falsificações}

Umberto Eco relembra e ironiza num texto polêmico, publicado na Itália em 1972, a estratégia do estudioso medieval. Segundo o grande intelectual italiano, misto de professor, romancista, cronista de jornal e cientista, o pesquisador da Idade Média fingia - o verbo é de Eco - nada criar, atribuindo sempre a outros aquilo que dizia ou aventava. Esse recurso à autoridade pregressa, de Aristóteles a Santo Agostinho, passando pela Bíblia, era certamente uma maneira de proteger-se de ataques e de simular uma humildade não necessariamente real ou presente. Era também uma forma de reverenciar a tradição em tempos de mudança lenta. Eco destaca que de René Descartes ao 
século XX aconteceria uma inversão de estratégia, com a valorização do novo acima de tudo num contexto de necessidade de desvelamento científico.

O século XXI representaria academicamente um retorno à Idade Média em termos de citações? No texto em questão, Eco afirma que na cultura medieval todos se preocupavam "em usar a mesma linguagem, as mesmas citações, os mesmos argumentos, o mesmo léxico" (1984, p. 91). Não se tem a mesma impressão lendo textos em publicações universitárias de 2018? A legitimação pela citação não se tornou uma norma incontestável? Cada área de conhecimento não obriga, pela força da estrutura, a aceitar, ou fingir aceitar, o conhecimento pregresso dos luminares do campo? Esta introdução em forma de desvio temático tem um objetivo a ser imediatamente confessado: situar tudo o que se vai dizer sob a proteção pregressa de uma autoridade: o próprio Umberto Eco. Fingimento, simulação ou reconhecimento de uma fonte incontornável para o bom tratamento do assunto em discussão?

Só o desenvolvimento da argumentação poderá esclarecer o leitor quanto às intenções, e possivelmente o caráter, do autor deste texto. As fake news, essas notícias falsas disseminadas nas redes sociais da Internet, constituem uma novidade jornalística e sociológica ou apenas a aceleração radical tecnológica de uma antiga modalidade de difusão de boatos, de falsificação de informações e de destruição de reputações? A obsessão pela origem de algo nem sempre é fundamental para o seu entendimento, podendo desviar o foco do estrago causado pela nova dimensão do fenômeno para uma espécie de genealogia estéril.

A reflexão sobre um fenômeno nas suas etapas anteriores pode, contudo, ajudar a compreendê-lo em sua estrutura e profundidade. As fake news parasitam um padrão jornalístico de empacotamento de informações. A lógica subjacente é a da manchete de jornal: o mais forte em primeiro lugar numa mescla de informação e apelo à emoção. Se jornalismo significa publicar o que estava encoberto antes de uma investigação, chamada no jargão profissional da imprensa de apuração, e assim permaneceria se dependesse do conforto e do interesse dos envolvidos, fake news é publicar aquilo que alguém gostaria de ler ou de ver, mesmo sendo inverídico, com o desejo de que se torne verdade por repetição ou por ser a pista forçada de uma realidade encoberta. 


\section{Da crítica de Eco à aceleração digital}

Umberto Eco abordou o tema da produção do falso com embalagem de verdadeiro num texto publicado em 2 de abril de 1978 no jornal italiano L'Expresso e reproduzido no livro Viagem na irrealidade cotidiana. Ele foi direto ao ponto como era seu hábito e seu estilo em ensaios sobre a semiologia do complexo cotidiano das sociedades modernas: "Eis então que na era da informática abre caminho a palavra de ordem para uma forma de guerrilha não-violenta (ou pelo menos não-sangrenta), a guerrilha da falsificação" (Eco, 1984, p. 234). Se, por um lado, a falsificação pode seguir simplesmente o desejo perverso de confundir e prejudicar terceiros, numa espécie de jogo cruel e gratuito como acontece nos chamados trotes telefônicos por meio dos quais alguém liga para o telefone de emergência dos bombeiros e anuncia um falso incêndio, por outro lado pode inscrever-se nessa categoria obscura que Eco rotulou de "guerrilha da falsificação".

No primeiro caso, irresponsabilidade pura no grau mais primário ou infantil pela qual o desperdício de energia e de tempo da vítima figura como a grande meta a ser atingida. O resultado alcançado não se traduz num benefício material ao autor, mas num gozo inglório e quase sempre solitário perpassado por um humor de mau gosto. No segundo caso tem-se um jogo motivado por razões políticas ou sociais mais profundas e orientado pelo abandono das normas éticas e dos princípios morais pertinentes, mesmo em situação de guerra. Guerrilha da falsificação ou guerra suja da informação. Umberto Eco enfatizou no seu texto premonitório a vulnerabilidade dos grandes sistemas. Brincou que era mais fácil desviar um avião do seu curso do que um bonde. O grande perigo era a falsificação de dinheiro com uma poderosa fotocopiadora.

Falsificar dinheiro é sempre um problema na medida em que se trata de um sistema dependente da confiança de cada usuário na valoração das notas e na veracidade material de cada peça a ser protegido por um pesado órgão central monetário. A desmaterialização do dinheiro, fruto da mesma aceleração tecnológica que permite a viralização das fake news, parece sinalizar que esse temor começa a ser neutralizado. Contra a facilidade de produzir cédulas, nada mais eficaz do que a passagem ao dinheiro imaterial, encontro enge- 
nhoso entre o valor simbólico e o simbólico como valor. Não mais um valor fictício sobre um pedaço de papel ou de metal. Apenas um valor realizado como operação de troca e de substituição de mercadorias, transferido sem materialidade por meio de operações virtuais.

Esse tempo descrito por Eco, tão próximo e tão distante deste ainda jovem século XXI, chega a parecer ingênuo quando comparado aos desafios e temores das sociedades atuais no apogeu do desenvolvimento tecnológico ao alcance da mão das maiorias antes quase silenciosas ou obrigadas a fazer barulho com meios mecânicos limitados. Passou-se dos primórdios da informática ao tempo da Internet e das redes sociais. Figuras antes subterrâneas ou inexistentes tornaram-se comuns e até, em algumas configurações, domesticadas como hackers e crackers. Para Umberto Eco a falsificação era regida, nas formas que apareciam então como novas, por um princípio teórico de crítica ao poder. Um novo modo de investir contra o velho poder. Potência contra poder? Todo sistema complexo necessita de milhões de pequenos consensos para subsistir. A crença no valor atribuído a cada cédula de dinheiro faz parte desse jogo consensual. O que acontece, porém, quando os consensos são atacados por falsificações que minam a confiança nos seus alicerces?

Era disso que falava Umberto Eco enquanto examinava as condições para a manutenção da confiança mínima necessária ao funcionamento da engrenagem social. Só bebemos a água que compramos engarrafada por confiarmos que nenhuma garrafa estará envenenada. Fora disso, para além dos controles sanitários, triunfaria a paranoia. Eco citou dois textos falsos, um poema de Pasolini e um artigo de Cassola, enviados ao jornal Corriere della Sera. Sem o restabelecimento da confiança, cada texto teria de ser entregue pessoalmente ao diretor do veículo. O primarismo das falsificações salvava o sistema. O que fazer, contudo, quando a sofisticação da cópia pode torná-la mais real do que o real, hiper-real? Só as suas imperfeições podem identificá-la. Contra a perfeição do falso só restaria, segundo Eco, uma astúcia fatal, "reagir às falsificações com outras falsificações" (1984, p. 236).

As fake news, numa hipótese extrema e caricatural, como podem e devem ser as hipóteses ad hoc, poderiam ser vistas como falsificações verdadeiras contra as falsificações dissimuladas dos veículos de comunicação com suas omissões, seleções, enquadramentos, hierarquias de edição e até mentiras 
deslavadas? Contra o consenso da verdade jornalística, essa mitologia da credibilidade por checagem e acerto no divulgado, sem qualquer explicação sobre o que foi eliminado, seriam as fake news um vírus disseminado para destruir o sistema e denunciar a sua falsidade ideológica? Eco via como convenção a ideia de que quem fosse dar uma notícia desse a notícia verdadeira. Se, porém, o informante passasse a mentir, o grupo não confiaria mais nele: "pode acontecer, num caso limite, que o grupo se vingue e passe a mentir para ele" (Eco, 1984, p. 237). As fake news poderiam ser mentiras em reação às mentiras da mídia? Eco soava o alarme: "mas suponhamos que o uso de não respeitar a condição mínima de verdade se alastre, e que cada um passe a mentir aos outros. O grupo se desagrega e começa a guerra de todos contra todos" (1984, p. 237). Esse parece ser o estágio atual da "guerrilha da falsificação”. As fake news não como reações conscientes às falsificações da mídia, mas como consequência de um método desmascarado e, mesmo assim, praticado com a arrogância do poder.

Designar as fake news como falsificações derivadas logicamente das contrafações midiáticas tradicionais não justifica nem absolve os falsificadores. Quando todos mentem não há mais verdade a defender? Falso. O trabalho de retorno a um conceito de verdade, no entanto, torna-se mais difícil. Umberto Eco afirma que nesse jogo cada um se torna vítima e subjugador. Vencem, ao menos provisoriamente, aqueles que se "unem para elaborar alguma técnica mais eficaz" que permita mentir "melhor e mais rapidamente do que os outros", pelo que uns se tornam "padrões dos outros" (Eco, 1984, p. 237). A mídia teria sido padrão das fake news? Estas, com novas técnicas de falsificação, estariam obrigando a mídia a tentar recuperar o terreno perdido? As matérias chamadas de "caça-cliques", com as quais, por meio de títulos sensacionalistas, jornalistas tentam atrair o interesse dos internautas mostram que as fake news são o novo padrão da atividade?

A guerrilha está em curso. Medidas são tomadas para tentar evitar o pior. No Brasil, em 2018, sob o impacto das eleições norte-americanas que levaram Donald Trump ao poder, as autoridades passaram a encarar as fakes news como um problema político grave. O Tribunal Superior Eleitoral organizou-se para impedir que as falsificações afetassem o resultado das eleições presidenciais e legislativas. Qual a reação possível e eficiente contra a guerra de 
todos contra todos? Umberto Eco sugeriu que "contra a falsificação desagregadora" surgiria ou "seria restabelecida uma ética da verdade muito puritana" pela qual "a maior parte (para defender as bases biológicas do consenso) se tornaria fanática da 'verdade' e cortaria a língua até a quem mentisse por utilizar uma figura de retórica" (1984, p. 238). A radicalização do politicamente correto, como verdade puritana e fanática segundo seus detratores, será o melhor antídoto contra as fake news e contra o jornalismo disseminador de meias verdades?

Umberto Eco provocou com uma boa fórmula: "a utopia da subversão produziria a realidade da reação" (1984, p. 238). Outra leitura, complementar certamente à de Eco, poderia sustentar que as fake news são uma distopia tecnológica em tempos de crise de referenciais e de relativismo pós-moderno. Contra a distopia da falsificação estimulada pelo mau jornalismo e pela violência política, a reação adequada seria fazer mais e melhor jornalismo sob o signo da verdade ponderada como uma equação cujos termos são apuração, verificação e comprovação.

\section{A falsificação como estratégia fatal}

O italiano Umberto Eco e o francês Jean Baudrillard compartilharam alguns interesses e tiveram pontos em comum: a descrição do hiper-realismo da cultura dos Estados Unidos, a preocupação com falsificações, certo estilo provocativo e irônico - embora o de Baudrillard fosse mais rebuscado, os paradoxos da cultura espetacular de mídia e o faro para as metamorfoses culturais por aceleração. Eco considerava o rádio e a televisão como "pluralidades incontroláveis" (1984, p. 179). Para Baudrillard eram meios que não se respeitavam mais e tomavam-se pelo acontecimento. As fake news, na linguagem de Jean Baudrillard, equivalente, no caso, à interpretação de Eco, podem ser vistas como estratégias fatais, "a simulação é o êxtase do real" (Baudrillard, 1996, p. 9). Eco fala em irrealidade cotidiana. Baudrillard mostra que na televisão "os fatos reais se sucedem numa relação perfeitamente extática, isto é, em traços vertiginosos e estereotipados, irreais e repetidos" (1996, p. 9). Verdadeiramente falsos. Falsamente verdadeiros. Todos numa linha de exibição fake. 
Para Baudrillard as coisas desapareciam por saturação e aceleração. Quando todos escrevem, não há mais escritores. Quando tudo é irreal, qual o sentido de denunciar o falso? A mais radical estratégia fatal talvez seja a aceleração do falso para resgatar a necessidade do verdadeiro como extrema-unção. Para Baudrillard o salto já havia sido dado: "não estamos mais no drama da alienação, estamos no êxtase da comunicação” (1996, p. 59). Nem verdadeiro nem falso, puro gozo na enunciação. Passagem da esperança de cura para a contemplação da metástase. Não se deve brincar com coisas tão sérias? Nem Baudrillard nem Eco brincavam. O francês denunciava contradições e revelava paradoxos. Usava a ironia como uma arma letal. Sobre as fake news talvez perguntasse: não serão elas a revelação de que a verdade morreu como uma manchete do dia anterior jamais refutada nem confirmada, apenas esquecida, superada, suplantada, neutralizada?

Contra a banalização da verdade pelo relativismo, a aceleração da mentira pelo cinismo. Estratégia fatal para o jornalismo com seu permanente discurso sobre a neutralidade, a imparcialidade, a isenção e a objetividade raramente praticados. Quatro termos usados quase como sinônimos. Ser neutro significa não ter posição pré-definida. Estar pronto a reconhecer a verdade de qualquer parte. Ser imparcial remete a não ter parte, não ter lado prévio capaz de condicionar o juízo. Tomar parte sem ser parte, como um juiz, que sem ser parte deve posicionar-se e julgar dizendo quem tem razão. Nada cognitivamente impede a isenção, que exige a cada situação o posicionamento a partir dos dados e evidências disponíveis para análise. A objetividade é o princípio do controle mais amplo possível da subjetividade. Definição negativa. Ser imparcial, como oposto de ser tendencioso, é outra maneira de afirmar a independência. Ser independente significa poder se posicionar a cada caso sem pedir licença a cada lado ou sem se sentir devedor de quem quer que seja. Nesse sentido, jornalismo é função. Cabe ao jornalista posicionar-se com base na sua consciência.

Jean Baudrillard sentia que essa utopia estava perdida: "Como a informação era bela no tempo da verdade! Como a ciência era bela no tempo do real! Como a objetividade era bela no tempo do objeto! Como a alienação era bela no tempo do sujeito" (Baudrillard, 1996, p. 78). E se, justamente, as fake news viessem para desmentir Baudrillard e os relativistas de quem ele zombava, 
reinstalando a verdade como horizonte possível? Para Baudrillard não poderia haver bom uso dos meios da comunicação, da mídia, num sistema de simulação. E se justamente as fake news forem a estratégia fatal, inconsciente ou até contra a consciência dos seus disseminadores, capaz de despertar as pessoas para a verdade não apenas como consenso molecular necessário à funcionalidade do sistema, não só como reação fanática à mentira odiosa, mas como entendimento tardio de que há verdadeiro e falso em estado bruto sem que isso se resuma a um desejo ingênuo em estado de brutalidade pré-filosófica?

Num pequeno livro de grande repercussão, América, Jean Baudrillard especulou: “a América não é nem um sonho nem uma realidade; é uma hiper-realidade. É uma hiper-realidade porque é uma utopia que desde o começo foi vivida como realizada" (1986, p. 26). As fake news são uma distopia hiper-real, desde o começo vivida como um pesadelo realizado. A mídia acostumou os indivíduos a desconfiar da verdade informando sem informar pessoas sem opinião própria. A estratégia fatal pode estar em usar involuntariamente a estratégia banal da falsificação como despertadora das consciências. A mídia também habituou cada um a ser visto como cliente. Pois bem, o cliente não quer ser contrariado. Se a verdade não o satisfaz, requer a falsificação. Se não é atendido, recorre ao yourself com ajuda do seu celular. O profissional de opinião é elogiado como isento quando sua posição coincide com a do destinatário. A lógica profunda das fake news consiste na veiculação do desejado, não do acontecido. Para funcionar melhor, cada notícia falsa precisa ser verossímil. Quanto mais verossímil, mais real, hiper-real. Desvelamento da mídia em seu estágio pornográfico inexorável? Fim de uma ilusão, a da verdade universal entregue por missionários da verdade? Retorno de uma missão, a do profissional capaz de separar verdade e mentira sem hesitação nem sofismas? Uma janela se abre. O que se verá através desse vão?

\section{Lula e a falsa capa da Forbes}

A história brasileira recente é repleta de notícias falsas. Em 2018, após o assassinato da vereadora fluminense Marielle Franco, do Partido Solidariedade e Luta (PSOL), de extrema-esquerda, surgiram notícias em redes sociais 
que a ligavam a um famoso traficante de drogas ${ }^{1}$. Era tudo intencionalmente falso. Outro caso emblemático de fake news no Brasil envolve o ex-presidente da República Luiz Inácio Lula da Silva, uma das vítimas mais recorrentes de falsificações suspostamente noticiosas. Em maio de 2012 circulou na internet uma capa da revista norte-americana Forbes com a chamada em letras garrafais "Billionaires" sobre uma foto do político brasileiro do Partido dos Trabalhadores (PT). Lula seria um dos duzentos homens mais ricos do mundo, com um patrimônio estimado em US\$2 bilhões.

Houve quem recebesse centenas de vezes essa informação falsa junto com comentários indignados sobre a corrupção no Brasil e a traição do líder popular. A capa da revista aparecia, conforme a fonte disseminadora, com fotos diferentes de Lula. Seis anos depois, um site chamado O Detetive - a verdade é o nosso objetivo, imparcialidade é o nosso lema! ainda denunciava: "Revista Forbes revela fortuna bilionária de Lula. 'Um dos mais ricos do mundo"”2. Forbes desmentiu formalmente que tivesse incluído Lula em uma lista de bilionários. O jornal brasileiro O Estado de S. Paulo repercutiu, em 28 de agosto de 2013, a negativa da publicação com o seguinte título: "Forbes esclarece viral que colocava Lula entre bilionários do ano"3.

Deixada de lado a rocambolesca genealogia dessa fraude, cabe pensar suas consequências ou desdobramentos. A informação falsa colou na biografia de Lula. A ideia de que ele acumulara um patrimônio incompatível com os seus ganhos cresceu, disseminou-se, passou de boato a investigação policial, processo, julgamento e condenação. Em 2018, o ex-presidente brasileiro foi preso

\footnotetext{
1 Marielle Franco, vereadora no Rio de Janeiro, socióloga, feminista, negra, gay, militante dos Direitos Humanos, foi executada, junto com seu motorista, Anderson Gomes, em 14 de março de 2018. Ela denunciava violência policial em favelas cariocas. Um deputado chegou a reproduzir no seu Twitter informações falsas contra ela. Diante das evidências, apagou a postagem.

2 Consultado em http://www.odetetive.com/2018/01/revista-forbes-revela-fortuna.html a 16 de julho de 2018 .

3 O jornal brasileiro destacou que o correspondente da Forbes no Brasil, Ricardo Geromel, publicara no site da revista uma nota intitulada "Is Lula, Brazil's Former President, A Billionaire?" Como respondeu, afirmou que o brasileiro nunca esteve numa relação da Forbes por não ter patrimônio para tanto. Ver Venturini, L. (2013, 23 de agosto). Forbes esclarece viral que colocava Lula entre bilionários do ano. O Estado de São Paulo. Consultado em https://politica.estadao.com.br/noticias/geral,forbes-esclarece-viral-que-colocava-lula-entre-bilionarios-do-ano,1067141 a 20 de dezembro de 2018.
} 
sob acusação de ter recebido um apartamento em troca de benefícios ilícitos concedidos para empresas da construção civil em contratos da Petrobras, estatal brasileira do ramo do petróleo. Não é difícil perceber que para alguns a informação falsa tornou-se, de algum modo verdadeira, o que faria dela uma verdade virtual anterior à verdade factual ou de direito.

As fake news seriam, num cenário caricatural extremo e cínico, do ponto de vista dos seus usuários ou disseminadores, pistas para apurações capazes de produzir verdades posteriores de interesse público. No caso de Lula, a justificativa seria ideológica e missionária, o que, em certo sentido, é uma redundância: usar o falso para revelar uma verdade profunda escondida sob uma aparência verossímil, a do líder popular de origem humilde e vida dedicada à política. Lula é o principal alvo brasileiro de notícias falsas ${ }^{4}$. A ele e sua família foram atribuídas fortunas colossais e a propriedade de terras imensas e de empresas de grande porte. Mesmo jornalistas de renome e de reputação, como Josias de Souza, ligado ao portal Universo Online, do Grupo Folha de S. Paulo, não hesitaram em forçar o título: "Pedidos de bloqueio realçam a fortuna de Lula" ${ }^{5}$. A justiça estava pedindo o bloqueio de R\$24 milhões em contas bancárias do ex-presidente da República, valor compatível com seu status de palestrante e de celebridade mundial, muito aquém do patrimônio de um bilionário, mas elevado para um ex-operário comprometido com os mais pobres.

Augusto Nunes, colunista da revista Veja, principal semanário brasileiro, adversária declarada de Lula e da sua ideologia, ousou fazer um título no limite entre a verdade e a falsa informação: "na modalidade conta corrente, Lula venceu o dono do Itaú"6. O ex-presidente mantinha na sua conta ban-

${ }^{4} \mathrm{O}$ site da revista brasileira Veja destacou que Lula é o brasileiro mais atingido por fake news seguido pelo presidente Michel Temer e por Sérgio Moro, o juiz que condenou Lula a prisão. Ver Bergamasco, D., Aguiar I., \& Campos, J. (2018, 12 de janeiro). Lula, Temer e Moro são os maiores alvos de notícias falsas. Veja. Consultado em https://veja.abril.com.br/ brasil/ranking-alvos-vitimas-noticias-falsas-fake-news-politica-brasil/ a 17 de julho de 2018.

5 Ver Josias de Sousa (2017, 17 de novembro). Pedidos de bloqueio realçam a fortuna de Lula (blog post). Consultado em https://josiasdesouza.blogosfera.uol.com.br/2017/11/17/ pedidos-de-bloqueio-realcam-a-fortuna-de-lula/ a 17 de julho de 2018.

6 Ver Nunes, A. (2017, 24 de julho) Na modalidade conta corrente, Lula venceu o dono do Itaú. Veja. Consultado em https://veja.abril.com.br/blog/augusto-nunes/na-modalidade-conta-corrente-lula-venceu-o-dono-do-itau/ a 17 de junho de 2018. 
cária corrente mais dinheiro do que o proprietário do Banco Itaú. O jogo de palavras leva o leitor desatento a pensar que Lula tem mais dinheiro do que o banqueiro. O DNA do procedimento está decodificado. Não é necessário ser repetitivo. As falsas informações acabam refutadas. $O$ efeito que provocaram, porém, dificilmente é desconstruído. O falso pavimentaria o caminho do verdadeiro. Numa lógica baudrillardiana, ou seja, de desmascaramento pela ironia ou pelo paroxismo do absurdo, seria o "bom uso" social do falso, uma hiper-realidade ou irrealidade cotidiana fazendo Eco - Umberto, com seu senso de humor, não desprezava um trocadilho - nas consciências manipuladas e sensíveis ao falso como repetição ou reforço de suas crenças, mitologias e estereótipos. É possível ouvir em qualquer lugar público uma anedota sobre Lula:

- Era tudo falso o que disseram sobre Lula.

- É mesmo. Então por que ele está na cadeia?

\section{Verdadeiro e falso}

A lógica das fake news é antiga: destruir reputações, fomentar o ódio, provocar celeuma, obter vantagens com o prejuízo alheio, gerar confusão, obter prazer com a propagação daquilo que atrapalha o discernimento, etc. Novidade é a tecnologia de produção, montagem e disseminação do falso. Quando todos podem ser emissores e difusores de dados, não há mais limite para a circulação do inverídico. Nunca foi tão fácil e rápido mentir para todos. A notícia falsa disputa com a verdadeira a atenção dos públicos. A sua vantagem é a liberdade que se dá para usar técnicas jornalísticas atreladas ao sensacionalismo para mexer com as emoções, mais especificamente as paixões, dos indivíduos.

Numa dimensão viral, como metáfora de desregulação ou de metástase, resgatando as ideias de Eco e Baudrillard comentadas anteriormente, cada jogador - pois há jogo, embora perverso, maligno, em campo - responderia ao falso com outro falso ou com doses sempre mais elevadas de falsificação. Só o falso seria capaz de neutralizar o falso na medida em que o verdadeiro se tornaria impotente para enfrentar a proliferação acelerada do seu oposto. 
A verdade exige tempo de apuração, de verificação e de ponderação. A falsificação ocupa os espaços vazios acelerando sempre mais o seu fluxo. Nessa perspectiva, a tecnologia deu ao falso o seu principal trunfo: a velocidade de difusão. Contra a discrição do verdadeiro, a obscenidade do falso. Contra a lentidão da verdade, a celeridade do celerado.

Face a um real fragilizado pela diversidade de pontos de vista, uma opinião relativizando a outra num jogo de soma zero, a falsificação oferece a robustez do hiper-real, mais real do que o real, mais enfática, mais definida e em sintonia com a percepção distorcida do indivíduo que reclama uma verdade clara e precisa, embora falsa, pela qual possa viver e morrer. Num tempo em que o relativismo não pode mais ser negado pela verdade do especialista, pois sempre pode existir outro especialista para sustentar o oposto, só a falsificação se dispõe a apresentar uma "verdade" incontestável.

As fake news alimentam-se de dois públicos paradoxalmente antagônicos e complementares: o que sabe da falsificação e não se importa, por considerá-la útil aos seus fins ideológicos, e o que adere ingenuamente a uma verdade inexistente por crença ou identificação, ou seja, por encontrar no falso aquilo que pensa ou imagina como sendo verdadeiro. Toma, portanto, o seu desejo por verdade e aceita o falso como evidência materializada da sua ilusão. Não raro, como na vulgata do pensamento medieval, a falsificação recorre a citações verdadeiras para legitimar o seu procedimento.

O grande desafio da verdade é o de frear a vertigem da falsificação como estratégia fatal, aquela que substitui a insegurança do jogo argumentativo, argumento e contra-argumento, ponto e contraponto, pela falsa segurança da afirmação contundente e autoconfiante que não admite contestação nem sequer discussão. A tarefa é trazer de volta para o terreno da apuração, da verificação e da demonstração quem passou a considerar mais eficaz, na guerrilha ideológica, o uso do falso como dispositivo de desestabilização do adversário por meio de uma aberração lógica: quando tudo é relativo, só o falso tem ar de verdadeiro e capacidade de convencimento. Uma verdade fraca, que afirma constante os seus limites, não consegue enfrentar uma mentira forte, que se apresenta como ilimitada. Parafraseando Heidegger - o fim deve remeter ao começo - para quem a essência da técnica não é técnica, a essência 
do falso não é a falsidade, mas, quem sabe, a sua competência para simular veracidade.

O antídoto contra a falsificação talvez esteja em voltar a acreditar profundamente na verdade. Como fazer isso quando tudo é interpretação? A justiça, por exemplo, não se contenta em aplicar a literalidade da lei. Entende que fora da interpretação tudo é falso. A verdade tornou-se uma etapa da grande mitologia iluminista defunta?

\section{Referências bibliográficas}

BAUdRILlard, J. (1986). América. Rio de Janeiro: Rocco (1986).

BAUDRILLARD, J. (1996). As estratégias fatais. Rio de Janeiro: Rocco.

ECO, U. (1984). Viagem na irrealidade cotidiana. Rio de Janeiro: Nova Fronteira. HeIDEGGER, M. (2002). Ensaios e conferências. Petrópolis: Vozes. 